Michael Timothy Law, When God Spoke Greek. The Septuagint and the Making of the Christian Bible (Oxford - New York: Oxford University Press 2013). 216 s. £20.99. ISBN 978-0-19-978172-0

\title{
ANNA RAMBIERT-KWAŚNIEWSKA
}

\author{
Instytut Nauk Biblijnych, Papieski Wydział Teologiczny we Wrocławiu \\ e-mail: anna.rambiert@gmail.com \\ ORCID: 0000-0002-9491-6786
}

Nie od dziś wiadomo, że Septuaginta (LXX) jest dziełem złożonym i niełatwym w interpretacji, a opowieść o jej początkach ujętą w Liście Arysteasza rozpatrywać należy w kategoriach legendy. LXX nie narodziła się wskutek jednorazowego wysiłku tłumaczy, ale powstawała przez kilka stuleci, a każda z jej ksiąg wymaga odrębnej dyskusji. Na rynku wydawniczym dominują monografie zbiorowe, ogromnie cenne dla badań nad Biblią Grecką, ale poruszające wiele kwestii, które nie składają się na spójny obraz. Tym cenniejsze wydają się prace jednego autora, który omawia LXX holistycznie i z pewnym dystansem właściwym znawcom tematu, nie popadając przy tym w nadmierną drobiazgowość. Obok monografii Michaela Timothego Lawa jest ich niewiele - wspomnijmy tylko o ważniejszych, choć nie najnowszych, które cytuje również autor recenzowanej pozycji: The Septuagint in Context: Introduction to the Greek Version of the Bible autorstwa Natalio Fernándeza Marcosa (2000), The Septuagint Jennifer Dines (2004) oraz o trwającym projekcie The Oxford Handbook of the Septuagint, którego jednym z redaktorów jest właśnie Law (wespół z Alison G. Salvesen).

Już krótki kontakt z monografią pozwala stwierdzić, że jest ona dziełem przemyślanym i podającym wiedzę o LXX w sposób nie tylko mądry, ale i atrakcyjny (już na pierwszej stronie publikacji znajdujemy informację o grecko brzmiących nazwach ksiąg biblijnych oraz kolorowej szacie Józefa, której wyobrażenia bazują na tekście LXX). Law dowodzi, że nawet osoby pobieżnie znające Biblię mają nieuświadomiony kontakt z greckim Starym Testamentem m.in. za pośrednictwem cytatów z LXX w NT. Wyjaśnia również, dlaczego LXX nie cieszyła się szczególnym zainteresowaniem aż do odkryć z Pustyni Judzkiej, które rzuciły nowe światło na proces formowania się tekstów biblijnych. Okazało się wówczas, że różnice między tekstami hebrajskim i greckim nie były jedynie owocem pomysłowości tłumaczy. Wciąż jednak nie doszło do rewolucji i nawet dla studentów specjalizujących się w księgach starotestamentowych LXX pozostawała terra incognita. Najważniejszym z powodów, dla których 
autor zdecydował się na napisanie książki, nie jest jednak wnikliwe ukazanie natury LXX, ale takie jej przedstawienie, by nawet jego rodzice byli w stanie zrozumieć jej wartość (s. 4). Takie popularyzujące podejście należy wciąż do rzadkości i jest niezwykle cenne. Sam autor wymienia jednak cztery kolejne przyczyny, dla których monografia może wydać się interesująca dla odbiorców (s. 4-6): po pierwsze, LXX pozwala zrozumieć hellenistyczny judaizm, a za jego pośrednictwem również NT i wczesne chrześcijaństwo; po drugie, LXX wpłynęła na kształt kanonu, ponieważ była tekstem wykorzystywanym przez autorów NT oraz wczesnochrześcijańskich - a skoro tak, tym bardziej uznać ją należy za tekst czcigodny; po trzecie, skoro chrześcijańscy pisarze korzystali z LXX, to właśnie ona, a nie Biblia Hebrajska, wpłynęła na kształt chrześcijańskiej teologii; po czwarte, w LXX odnajdujemy alternatywne lekcje, niekiedy starsze od znanego nam tekstu hebrajskiego. Mówienie, że lektura tekstu hebrajskiego przenosi nas ad fontes, jest więc pod wieloma względami błędne.

Rozdział drugi poświęca Law kontekstowi historyczno-kulturowemu, zaczynając od cytatu z Plutarcha (s. 9), wedle którego Aleksander Macedoński za sprawą swych podbojów uczynił świat szczęśliwszym, ponieważ cywilizowanym. Nie Aleksander stoi jednak u początków opowieści, ale Nabuchodonozor, który uprowadził mieszkańców Judy do babilońskiej niewoli. Autor opisuje lakonicznie czasy wygnaniowe. Więcej miejsca poświęca epoce perskiej i Cyrusowi, z którego czasami łączy pierwszą redakcję księgi praw - serca Tory. Na okres perski datuje również dzieło Deuteronomistów. Księgi mądrościowe, jak słusznie zauważa, sięgają nawet czasów hellenistycznych. Law podkreśla w ten sposób, że epoka perska i czasy hellenistyczne do 170 r. przed Chr. były okresem pokoju sprzyjającym działalności pisarskiej, a pod dominacją ptolemejską żydzi osiągnęli swoje kulturalne apogeum (s. 15). W dalszej części rozdziału autor wyjaśnia, dlaczego żydzi ostatecznie stanęli do walki (s. 13nn). Przełom przychodzi wraz z Aleksandrem Wielkim, którego można postrzegać jako „wcieloną rewolucję". To on wprowadził świat w okres grecki, on stał się główną przyczyną, dla której przetłumaczono żydowskie księgi na grekę, a zatem on przyczynił się pośrednio do ekspansji chrześcijaństwa w śródziemnomorskim świecie. Dlaczego? Law wyjaśnia, że ekspansja hellenizmu była tak szybka i skuteczna, jak żadna inna w historii świata - a to oznacza, że każdy, kto się z nią mierzył, musiał opowiedzieć się za nią lub przeciw niej. Dzięki klimatowi Egiptu, który sprzyja zachowaniu źródeł pisanych, posiadamy sporo informacji pozwalających scharakteryzować stosunek żydów do hellenistów - przede wszystkim w Aleksandrii. Law słusznie zauważa, że hellenizacja nie dotyczyła żydów wyłącznie w diasporze, ale również w Palestynie. I choć znalazła się grupa, która sprzeciwiła się hellenizacji i wywołała powstanie, to jednak nie można zapomnieć, że Machabeusze mówili po grecku i przestrzegali greckich 
protokołów politycznych, nie wspominając nawet o tym, że z nich właśnie wyrosła mocno zhellenizowana dynastia hasmonejska.

Trzeci z rozdziałów Law otwiera cytatem Ulricha, który twierdzi, ze trudno mówić o Biblii w I w. przed lub nawet w I w. po Chr. (s. 19). Czym jest więc LXX? Law zauważa, że choć wciąż mówi się o Biblii w odniesieniu do zbioru ksiąg istniejącego przed i w czasach Jezusa, coraz silniej wzrasta tendencja do zastępowania terminu „Biblia”, który oznacza zbiór ksiąg skanonizowanych, słowem „pisma”, obejmującym różne księgi o religijnym autorytecie. Fakt ten jest dla badacza punktem wyjścia do podkreślenia, skąd bierze się odmienność LXX od BH w niektórych księgach (zwłaszcza Wj, Sm, Krl, Jr, Ez, Est, Dn). W czasach poprzedzających unifikację tekstu istniały różne tradycje rękopiśmienne, które w większości wypadków przepadły. W związku z tym LXX jest częstokroć jedynym źródłem alternatywnych wersji dla tekstu hebrajskiego. Badacz podkreśla przy tym, że choć TM może prezentować tradycje bardzo dawne, w swej naturze jest jednak tekstem średniowiecznym, którego nie należy mylić z tekstem oryginalnym Biblii Hebrajskiej - pomimo jego powszechnego wykorzystania w studiach biblijnych. Law docenia Pięcioksiąg Samarytański, uwzględniając jego odmienną od LXX naturę (pomimo ich podobieństw przeciw TM). O ile bowiem LXX jest przekładem, o tyle PS jest jedną z wersji Tory hebrajskiej z sektariańskimi modyfikacjami. Reasumuje, że choć dość wcześnie uznano istnienie trzech głównych tradycji rękopiśmiennych, jednak odkrycia znad Morza Martwego przekonały badaczy, że wewnątrz każdej z nich istnieje wielka różnorodność. Uświadomiły im również, że odmienność LXX nie jest zawiniona/zamierzona przez tłumaczy, ale szukać jej należy w samym tekście hebrajskim - starszym od TM o około 1000 lat (s. 25).

W rozdziale czwartym autor zajął się tłumaczami LXX (s. 33-42), zauważając, że mogli mieć świadomość ciążącej na nich odpowiedzialności, ponieważ w kulturze śródziemnomorskiej często posługiwano się tłumaczeniami i znano wartość dobrze wykonanych przekładów. Diaspora żydowska w Aleksandrii, wedle Lawa, dysponowała w III w. przed Chr. wystarczającą liczbą uczonych mężów, by przetłumaczyć hebrajską Torę. Przekład ten był projektem bez precedensu (nigdy wcześniej nie podjęto się tłumaczenia tak obszernego tekstu świętego na inny język), był również koniecznością, by judaizm przetrwał poza Judeą. Jedynym źródłem, które wyjaśnia historię powstania LXX, jest List Arysteasza. Law słusznie jednak zauważa, że proces tłumaczenia został streszczony w zaledwie dwóch zdaniach, co do których rodzi się wiele pytań - czy tłumaczono w zespołach, czy też każdy z tłumaczy dokonał własnego przekładu, który następnie porównał i przedyskutował z innymi? Odpowiedzi na te pytania nigdy jednak nie poznamy. Co ciekawe, choć przytacza sądy uczonych na temat Listu, sam go ani nie kwestionuje, ani nie próbuje wydobywać z niego cząstek 
prawdy. Czyni to jednak pośrednio, gdy identyfikuje tłumaczy Pentateuchu z LXX, którymi byli wedle niego aleksandryjscy zhellenizowani żydzi (s. 40). Większy kłopot dotyczy przekładu innych ksiąg, zważywszy na dalsze formowanie się kanonu hebrajskiego. Law zauważa jednak, że za dalszym przekładem nie stała raczej motywacja kanoniczna, ale raczej nowa świadomość literacka środowiska żydowskiego (s. 42).

Trzeba autorowi przyznać, że wielkim walorem jego książki jest nieustanne wzbudzanie ciekawości w odbiorcy. Bezsprzecznie do ciekawych zaliczyć należy uwagę, że gdyby LXX powstała niedługo później, byłaby tekstem zgoła innym, ponieważ niebędącym owocem tekstualnej różnorodności. Równie interesujący jest także tytuł piątego rozdziału (s. 43-57) „Gog i jego nie-tak-wesoły konik polny", który autor tłumaczy jedynie w lakoniczny sposób (s. 54). O czym jest mowa w tym rozdziale? O różnicach tekstualnych w BH i LXX. Law słusznie zauważa, że LXX nie poświadcza żadnych rewelacji w rodzaju „Salomon był celibatariuszem" (s. 44), ponieważ jest de facto bardzo podobna do znanej nam $\mathrm{BH}$. Jest jednak na tyle różna, by poświadczać istnienie innych tradycji - zwłaszcza gdy zgadza się choćby z Pięcioksięgiem Samarytańskim. Dalej omawia Law charakter i jakość przekładu oraz odmienność nie tylko Pentateuchu, ale również całej historii Izraela. Zauważa, że panuje powszechna zgoda co do znacznego uszkodzenia Ksiąg Samuela, które zostały później uzupełnione i poszerzone. Dlatego np. historię Dawida i Goliata z LXX uznać należy za tradycję starszą. Co ciekawe, LXX zmienia również spojrzenie na niektóre z ksiąg - dowodzi choćby, że Dzieło Kronikarza nie jest wyciągiem z ksiąg Samuela i Królewskich, ale efektem pracy z odmienną wersją tekstu hebrajskiego. Co do ksiąg prorockich i poetyckich Law również w tym wypadku poświęca trochę miejsca najciekawszym przykładom - bardzo chwali choćby przekład Izajasza, który odznacza się niezwykłą starannością oraz kreatywnością (s. 52). U Jeremiasza dostrzega braki teologii Dawidowej, zaś w Ezechielu podkreśla różnice w układzie materiału oraz brak w. 36,23-38. Co do Proroków mniejszych zauważa Law na przykładzie Amosa, że tłumacze LXX skłaniają się ku egzegezie symbolicznej, rozszerzając popularne w hellenistycznym judaizmie motywy. Tekst Daniela ma wiele dodatków, poetyzowany grecki tekst Hioba mógł ulec skróceniu po zlikwidowaniu licznych powtórzeń. Modyfikacje w Psalmach są kwestią korekt tekstu hebrajskiego, różnice w Księdze Przysłów - odmienności tekstu hebrajskiego - pisze autor, posługując się każdorazowo przykładami (s. 55-56). Wciąż jednak Law podkreśla, że rozdział ten jest niedoskonały, ponieważ LXX nie ma punktu odniesienia w kanonie hebrajskim.

Rozdział szósty (s. 58-74), również o intrygującym tytule „Ptasie odchody, kamienowane słonie i wybuchające smoki”, poświęca autor księgom przynajmniej częściowo uznawanym za apokryficzne czy też pseudoepigraficzne, które 
narodziły się między III w. przed Chr. a II w. po Chr., gdy Biblia Hebrajska nabrała ostatecznego kształtu, a które zostały włączone do LXX i cieszyły się autorytetem tak wśród żydów, jak i pośród chrześcijan. Podkreśla przy tym, że to nie kwestia symulowanego autorstwa stała się przyczyną ostatecznego nieprzyjęcia niektórych pseudoepigrafów do kanonu - choć pewne mogły znaleźć swoje miejsce w Biblii innej denominacji. Inną kwestią pozostają greckie księgi LXX, których oryginałów semickich nie posiadamy, przy czym styl wydaje się na nie wskazywać (jak Jdt i ListJr). Choć Law nie wyklucza jednak, że pisarze mogli imitować semityzujący styl innych tekstów LXX (np. 1 i 2 Ezd, dodatki do Est, 1 Mch, dodatki do Dn). Autor omawia wnikliwiej każdy z tych przypadków. Debata o kanoniczności większości ksiąg i idący za nią wybór jednego konkretnego tekstu dla każdej z nich zakończyła okres pluralizmu w II w. po Chr.

Kolejny z rozdziałów (s. 75-84), rozpoczynający się od cytatu z Tova odnośnie do TM, poświęcił Law rewizjom tekstu LXX do I w. po Chr., które doprowadziły do powstania zbioru pism, po który sięgnęli następnie Masoreci. Były one, jego zdaniem, efektem konfrontacji z wielością tekstów - zarówno greckich, jak i hebrajskich. W rozdziale tym ukazuje Law starożytność Biblii Greckiej względem TM i istniejącą fałszywą perspektywę w ocenie procesu kształtowania tekstu, jako zmierzającego do unifikacji, do formy, którą dziś nazywamy Biblią Hebrajską (s. 76). Za przykład podaje słynne odkrycie z Nahal Hewer, gdzie pośród szczątków osób poległych w postaniu Bar Kochby odkryto fragmenty Proroków mniejszych, stanowiące dowód na będący w toku intensywny proces rewizji oraz ukazujące sosowane metody rewizji tekstu (takie same jak w Sm-Krl, Pnp, Rt, Lm i Koh! s.77). Ową rewizję nazwano kaige. Inną kwestią jest ustalenie kanonu, który Law, posługując się przykładem Ajschylosa, Sofoklesa i Eurypidesa, przy wtórze Homera i Arystofanesa, wydaje się uznawać za ograniczający i subiektywny z politycznego punktu widzenia, a z pewnością uznaje go za ostateczną przyczynę zaginięcia czy też nieznajomości niektórych z poczytnych ksiąg (jak to się stało z dramatami Agatona czy Frynicha). Bardzo ciekawie i krytycznie odnosi się Law do całego zjawiska ustalania kanonu, szukając nie tylko jego dobrych stron. Ponadto stwierdza słusznie, że nie wszystko, co uchodziło za Biblię, weszło ostatecznie do kanonu (s. 82.)

Z chrześcijańskiego punktu widzenia niezwykle ważne są rozdziały ósmy (s. 85-98) i dziewiąty (s. 99-116), poświęcone tekstom LXX w NT. Pierwszy z nich dotyczy głównie terminologii LXX adaptowanej przez NT oraz jej teologii (np. Syn Człowieczy z Mt i 1 Hen, kyrios w odniesieniu do Jezusa czy parthenos z Iz 7,15 do Maryi), a także problemu cytowania/inspirowania autorów NT księgami niewłączonymi do kanonu żydowskiego (Mdr, 2 Mch, Syr, Tb), które musiały jednak być odczytywane w synagogach tak Palestyny, jak diaspory (s. 91). W rozdziale dziewiątym autor zajmuje się dokładnymi 
cytatami z LXX, które jak słusznie zauważa Law, lepiej przystawały do kontekstów nowotestamentowych niż teksty w wersji hebrajskiej. Wpływu LXX na Ewangelie dowodzi biblista na przykładzie mowy Jezusa w nazaretańskiej synagodze, porównując teksty Mk i Łk z LXX (s. 100-102). Wspomina również pisma Jana, który używał wyłącznie LXX, niekiedy osobiście ją modyfikując (s. 102). Nawet Paweł, znający przecież źródła hebrajskie, również chętniej sięgał po wersję grecką, której używał z dużą dozą wolności, wielokrotnie modyfikując jej pierwotny przekaz! (s. 105nn). Dowodzi tym samym, że LXX była de facto Biblią chrześcijan aż do czasów Hieronima (rozdział dziesiąty, s. 117-127), z niej czerpią przecież ojcowie Kościoła, którzy budowali swoją argumentację, opierając się na tekstach greckich, zwłaszcza w dyskusji z żydami, choć także z poganami. Również w późniejszych czasach LXX żywo wpływała na płynność kanonu Starego Testamentu, który ewoluował aż do okresu reformacji. Rozdział dziesiąty i jedenasty poświęca Law dookreśleniu terminów „kanon” i „święte pisma" (scriptures), zauważając, że o ile pisma mogą istnieć bez kanonu, o tyle kanon nie może zaistnieć bez nich (s. 121). Zauważa jednak, że ojcowie Kościoła unikają komentowania tych ksiąg LXX, które uchodzą za apokryficzne (deuteronomiczne). Nie zmienia to jednak faktu, i Law podaje znaczące tego przykłady, że deuterokanoniczne/apokryficzne (w zależności od kanonu) księgi LXX stale oddziaływały na egzegezę patrystyczną oraz były dyskutowane w wielkich sporach doktrynalnych, a kanon ST pozostawał bardzo elastyczny. Law podkreśla również, że wielu pisarzy jeszcze w IV w. śmiało opowiadało się za natchnieniem LXX, która pozostawała tekstem bazowym dla chrześcijańskich myślicieli, cytujących z niej fragmenty historii Starego Przymierza aż do X w.

Ostatnie dwa rozdziały (s. 140-166) omawiają stopniowe odchodzenie od LXX - począwszy od Orygenesa i jego Heksapli, za sprawą której trafiła do obiegu zrewidowana wersja LXX - oraz zwyczaj odwoływania się w dyskusji do tekstów akceptowanych przez żydów, co przechylało szalę na stronę tekstu hebrajskiego. Najważniejszą rolę w tym procesie odegrał Hieronim ze swą Wulgatą oraz faworyzowaniem Biblii Hebrajskiej - nie zamierzał on nawet wdawać się w dyskusję z Augustynem broniącym powagi LXX i grożącym schizmą Wschodu i Zachodu. Jednak kluczowym etapem był rozwój chrześcijańskiej hebraistyki i renesansowa fascynacja językiem hebrajskim, które wpłynęły ostatecznie na przegraną LXX, o czym przeczytamy w Postscriptum (s. 167-171).

Bezsprzecznie książka Lawa jest osiągnięciem niemałym i dobrze ukazującym naturę LXX, jej historię, dynamikę, odbiór, recepcję, a nawet legendy, którymi obrosła. Autor krytycznie odnosi się do dobrze dobranych tekstów źródłowych, komentując zarówno teksty biblijne, jak i patrystyczne z dużą swobodą, co znacznie ułatwia odbiór monografii. Warte uwagi są również humorystyczne komentarze autora oraz chwytliwe tytuły, które stały się już 
co prawda przedmiotem krytyki i zarzutu o trywializację w innych recenzjach naukowych (zob. Moisés Silva w: The Westminster Theological Journal 76 (2014) 227), jednak moim zdaniem pozwalają one na moment wytchnienia dla czytelnika, który uważnie śledzi tok myślowy autora. Warto tu wspomnieć, że atutem książki jest umieszczenie przypisów po Postskrypcie - układ taki dobrze koresponduje ze stylem autora i nie burzy narracji.

Law w swoich analizach równie dobrze odnajduje się w badaniach tekstualnych, jak i w zagadnieniach kulturowych. Do takich uwag tekstualno-kulturowych należy choćby ta zaczerpnięta z NT: słowa „,zy nie czytaliście” (Mt 12,3) „słyszeliście, że powiedziano" (Mt 5,21) świadczą, według Lawa, o tym, że LXX używano w synagogach. Zjawisko to poświadczają zresztą obecne w rękopisach LXX podziały tekstów na kolejne czytania. Choć Law nie ma zamiaru przewartościowywać LXX kosztem tekstu hebrajskiego, można odnieść wrażenie, że jest wielkim zwolennikiem tej pierwszej, a jego sympatia względem ST pierwszego Kościoła znajduje w bardzo logicznie ułożonej monografii jego autorstwa pełne uzasadnienie, dzięki bogactwu przykładów oraz uwydatnieniu ogromnego autorytetu Biblii Siedemdziesięciu, którym cieszyła się ona od hellenistycznej starożytności po kilka pierwszych stuleci wieków średnich. 